$\xi=$

\title{
Assesment and evaluation of excess lifetime cancer risk for Occupants of university of Uyo permanent campus, Nigeria
}

\author{
Sunday Edet Etuk, Akaninyene Daniel Antia, Okechukwu Ebuka Agbasi * \\ Department of Physics, University of Uyo, Uyo, Akwa Ibom State, Nigeria \\ *Corresponding author E-mail: ebukasean09@yahoo.com
}

\begin{abstract}
This paper presents the results of ambient radioactive radiation, radiation health hazard indices and excess lifetime cancer risk estimation within University of Uyo campus, Use Offot, Uyo, Niger Delta region of Nigeria. Mean annual outdoor and indoor equivalent doses of $0.284 \mathrm{mSv} / \mathrm{yr}$. and $0.854 \mathrm{mSv} / \mathrm{yr}$. respectively were recorded, being less than $1 \mathrm{mSv} / \mathrm{yr}$. maximum recommended limit for general public. Mean annual outdoor and indoor effective doses of $0.174 \mathrm{mSv} / \mathrm{yr}$. and $0.645 \mathrm{mSv} / \mathrm{yr}$. respectively with a total of $0.819 \mathrm{mSv} / \mathrm{yr}$. were computed. The mean outdoor and indoor ELCR values of 0.61 x10-3 and 2.26 x 10-3 respectively, with a mean total of 2.87 x 10-3 were also computed. The results though higher than the world's average, are comparable with those of some other locations within the Niger Delta region.
\end{abstract}

Keywords: Radioactive Radiation; Equivalent Dose; Effective Dose; Excess Lifetime Cancer Risk; University of Uyo Campus.

\section{Introduction}

Apart from water, food and air, other areas of interest to the international community include environment, safety and health. It has been asserted that even the light and heat that we have been getting daily from the sun is as the result of thermonuclear reaction (Johnstone, 1990). Johnstone further observe that radiation in various form is around us all the time, naming common examples to include heat, sunlight and radio waves, while nuclear radiation and $\mathrm{x}$-rays are special type, called ionizing radiation which can be harmful if not controlled. The assertion is supported by Qureshi et al (2014) who report that radiation in our environment comes from the cosmogenic, anthropogenic and primordial sources, with primordial radioactivity being widespread in the earth environment. This is in support of the report of UNSCEAR $(1988,2013)$ that cosmic sources and earth crust, together with artificial sources of radiation resulting from medical applications, nuclear industry and nuclear bomb explosions contribute to an average of about $2.5 \mathrm{mSv}$ radiation dose per year for each inhabitant of the earth. It has however been reported that there is no heritable effects following radiation exposure UNSEAR (2001). Physical factors that health effects depends on include body diameters and height among others. This explains why children are more at risk than adults. Equally shorter people receive higher dose from radioactivity distributed in and deposited on the ground than tall people. Physiology and metabolism also determine dose at different ages. According to Mehra et al (2010) and Mazzilli and Sauela (1999) natural radioactivity is wide spread in the earth's environment and it exists in various geological formations in soils, rocks, plants, water and air. ${ }^{238} \mathrm{U},{ }^{232} \mathrm{Th}$ and ${ }^{40} \mathrm{~K}$ are main radioactive materials of long-lived radionuclides and are known as naturally occurring Radionuclide materials (NORMs). Natural radioactivity accounts for over $95 \%$ of the total radiation dose to the world population while artificial radioactivity contributes less than 5\% (Solomon 1986). This however depend on geological formulation, indicating that natural radioactivity concentrations vary from region to region in the world. Geological formation is therefore the source of continuous radiation exposure to inhabitants of the environment including human, leading to radiological contamination in our environment (Rafique et al 2013). This makes the survey of environmental radioactivity and ionizing radiation distribution within any environment, especially newly habitable environment, and of course, equivalent dose measurement very important for the purpose of establishing baseline data for future radiation impact assessment, radiation protection and exploration (Rami et al 2005).

Radioactivity level and equivalent dose has been reported by some researchers in some locations of Niger Delta Region of Nigeria (Etuk et al 2017; Etuk et al, 2015; Esen et al, 2015; Akpabio et al, 2005; Ekpo, 1996; Chad-Umoren et al, 2010; Agbalaba and Meindingo, 2010; Arogunjo et al 2004; Avwiri and Ebeniro, 1998; Inyang et al, 2009; Obioha and Okonkwo, 2001, Sadiq et al, 2010a Sadiq et al, 2010b; Avwiri and Olatubusun, 2014; Babalola, 1984; Ekpo and Inyang, 1998; Solomon 1986; Ibeanu 1999). Despite all these reports, it suffices to note that the permanent site or campus of University of Uyo at Use Offot, Uyo in Akwa Ibom State Nigeria has never been studied before for radioactivity levels. University of Uyo permanent campus is located at Use Offot in Uyo local Government Area of Akwa Ibom State Nigeria. Its coordinates lies between Latitude 5.0281 and Longitude 7.9734 and Latitude 5.0466 and Longitude 7.9869.

The aim of the present study is to determine the dose rates in order to assess the health risks, if any, and to compare the equivalent dose, hence, establishing baseline data for future radiation impact assessment and necessary radiation protection remedy if need be.

\section{Study area}

This research was carried out at the permanent site of the University of Uyo, Use Offot in Uyo, located within Latitude 5.0281E 
and Longitude 7.9734N and Latitude 5.0466E and Longitude $7.9869 \mathrm{~N}$.

The area has estimated terrain altitude above sea level from 54 $86 \mathrm{~m}$. The site is characterized by heaps of rocks, concrete buildings with tiles and painted walls, most of which are newly built, a population of about 8500 staff and students, surrounded by green vegetation, mainly palm trees and other shrubs and weeds, minimarket, refuge dump sites, laboratory chemicals and drugs from laboratories and medical Centre, students hostels, office accommodations and classroom blocks, herds of cattle and their rearers, stationary and motional vehicles, generating plants and science equipment among others. The site is within the Niger Delta Region of Nigeria where oil and gas exploration is in the increase, hence the site is not free from the effect of gas flaring activities.

The study site where the survey locations are within, is a public institution where students, staff and the general public are found. The institution's laboratories workshops, medical Centre, store some chemicals, reagent, equipment, rock, mineral elements, research samples brought in from other sites, drugs, granite and assorted rocks and other building materials such as tiles roofing and ceiling materials, assorted paints, may contribute to background radiation. It is expedient to carry out survey to know the level of radioactive radiation with reference to the maximum permissible level in order to find out whether it calls for the attention of regulatory control agencies, to make recommendations based on findings, and to establish a baseline for future impact assessment, bearing in mind that no radioactive survey had ever been carried out at the site prior to this present study.

\subsection{Materials}

A portable inspector Alert TM Nuclear radiation Monitor (model GLR 61 - 6AM6-9V serial Number 33333 Quality 1 made in USA by International Medcom) having GM tube with a fragile window, was used for the detection and measurement of the radiation equivalent dose. The handheld nuclear radiation monitor, the inspector alert TM was first calibrated to detect and measure equivalent dose in $\mu \mathrm{Sv} / \mathrm{hr}$. The handheld radiation monitor measures alpha, beta, gamma and x-radiation. The monitor has facilities for wide variety of digital displayed readings in $\mathrm{mR} / \mathrm{hr}$., $\mathrm{CPM}, \mathrm{CPS}$ or $\mu \mathrm{Sv} / \mathrm{hr}$. with a switch for setting to the unit required for measurement. It has also provision for Audio alert in addition to the digital display together with total/timer setting. The radiation measurement which is operated by a $9 \mathrm{~V}$ battery was set to $\mu \mathrm{Sv} / \mathrm{hr}$. range for this study. Global Positioning System meter (GPS) was also used for the geographical identification of the study locations in terms of latitude, longitude and altitude.

\section{Radioactivity measurements}

\subsection{System used for measurements}

A total of 45 (forty five) locations within the study site were selected for the experiment. They include; Physics Department, Faculty of Science (First Floor), Faculty of Science (Ground Floor), CHM Veranda, Faculty of Science Library, Waste Bin, First Market (Faculty of Science), Second Market (Faculty of Science), Multipurpose Hall, New Science Block 1, New Science Block 2, New Science Block 3, Convocation Arena 1, Convocation Arena 2, Convocation Arena 3, Botany Garden, Refuse Dump, Heap of Assorted Rock, Heap of Stone, Heap of Granite, Heap of Assorted Stones, Heap of Rods, New Boys Hostel, Heap of Dump Building material waste, Tiles Behind Boys Hostel, Mini Water Station (Not Operational) New Lecture Theater (500 capacity), Propose Eatery Center, Refuse Dump behind Boys Hostel, Engineering workshop, Engineering Laboratory, PTDF, ELF, Central Library, Toilet Behind New School Block (male and fe- male), Alumni Sport hall, Alumni Center, New Administrative Block, Postgraduate School, Health Center, 500 capacity Lecture theatre (TETFUND), Main Gate, Electrical Power station and Water pumping station.

The nuclear meter was first powered and switched on and allowed to absorb radiation for about 10 minutes to get stabilized and calibrated. Five hundred (500) in-situ measurements were taken per study location by holding the radiation monitor about $1.0 \mathrm{~m}$ away from the target each time and the mean calculated with standard error estimated. That was done for the 45 (forty five) selected study locations within the site. The measurements were taken in micro-Sievert per hour $(\mu \mathrm{Sv} / \mathrm{hr}$.). The equivalent dose rate in $\mu \mathrm{Sv} / \mathrm{hr}$. from the survey meter was converted to annual equivalent dose rate in $\mathrm{mSv} / \mathrm{yr}$. employing the mathematical relationship given by Marilyn and Maguine (1995), Etuk et al (2015), thus:

$H T_{a}=\delta \times \mu \times 24 \times 365 \times 10^{-3}$

Where $\delta=H T / Q$, being the absorbed dose

HT is equivalent dose in (meter reading) $\mu \mathrm{Sv} / \mathrm{hr}$.

$\mathrm{HT}_{\mathrm{a}}$ being annual equivalent in $\mathrm{mSv} / \mathrm{yr}$.

$\mu$ is the occupancy factor, expressing the proportion of the total time which an individual is exposed to radiation UNSCEAR (1998 and 2000) recommend indoor and outdoor occupancy factors of 0.8 and 0.2 respectively.

$\mathrm{Q}$ is the quality factor equal to 1

$H T_{a p}=1.752 \times H T\left(m S v y r^{-1}\right)$

And

$H T_{i i}=7.008 \times H T\left(m S v y r^{-1}\right)$

Where $\mathrm{HT}_{\mathrm{a} o}$ expresses outdoor annual equivalent dose and $\mathrm{HT}_{\mathrm{ai}}$ denotes indoor annual equivalent dose.

Standard Error SE was equally calculated for each of the locations using the quotient of the range of values for the location and the number of measurements taken for that location, the formula which abounds in several reports and statistic books.

\subsection{Radiation indices measurements}

Inhabitants of the area are exposed to radioactive radiations, gamma rays, alpha particles among others, from radioactive elements such as Potassium-40, Thorium-232, Radium-226 and Cobalt-60 contained in terrestrial materials (Mazzili and Savera 1999). These and others contribute to the collective Impact of activity concentrations. In order to assess in a single parameter; radiation indices including equivalent activity or equivalent dose, annual equivalent dose, outdoor and indoor doses, annual effective dose and excessive lifetime cancer risk were measured and calculated.

\section{Result}

\subsection{Equivalent dose}

Equivalent dose (HT) measured for outdoor locations ranges between 0.0714 to $0.270 \mu \mathrm{Sv} / \mathrm{hr}$. with mean of $0.142 \mu \mathrm{Sv} / \mathrm{hr}$., while that of indoor locations is between 0.090 to $0.185 \mu \mathrm{Sv} / \mathrm{hr}$., with a mean of $0.133 \mu \mathrm{Sv} / \mathrm{hr}$. The results is as shown in Tables 1 and 2 respectively. 
Table 1: Equivalent Dose Rate $\left(\mathrm{Ht}_{\mathrm{o}}\right)$, Annual Equivalent Dose Rate $\left(\mathrm{Ht}_{\mathrm{ao}}\right)$ External Dose $\left(\mathrm{D}_{\mathrm{o}}\right)$, Annual Effective Dose $\left(\mathrm{E}_{\mathrm{O}}\right)$ and Excess Lifetime Cancer Rate (ELCR)

\begin{tabular}{|c|c|c|c|c|c|c|c|c|}
\hline Location (Outdoor) & Altitude (m) & Latitude & Longitude & $\mathrm{HT}_{\mathrm{o}}(\mu \mathrm{Sv} / \mathrm{hr})$. & $\mathrm{HT}_{\mathrm{ao}}(\mathrm{mSv} / \mathrm{yr})$. & $\begin{array}{l}\mathrm{D}_{0} \\
(\mathrm{nGy} / \mathrm{hr} .)\end{array}$ & $\begin{array}{l}\mathrm{E}_{0} \\
(\mathrm{mSv} / \mathrm{yr} .)\end{array}$ & $\begin{array}{l}\text { ELCR } \\
\times 10^{-3}\end{array}$ \\
\hline O-1 & 80 & 5.0404 & 7.9792 & $0.1550 \pm 0.004$ & $0.2716 \pm 0.0009$ & 0.000155 & 0.1901 & 0.6653 \\
\hline $\mathrm{O}-2$ & 74 & 5.0393 & 7.9799 & $0.0916 \pm 0.012$ & $0.1605 \pm 0.0107$ & 0.000091 & 0.1123 & 0.3931 \\
\hline O-3 & 69 & 5.0390 & 7.9802 & $0.0714 \pm 0.019$ & $0.1251 \pm 0.0987$ & 0.000071 & 0.0876 & 0.3065 \\
\hline $\mathrm{O}-4$ & 74 & 5.0394 & 7.9805 & $0.0763 \pm 0.101$ & $0.1331 \pm 0.0197$ & 0.000076 & 0.0936 & 0.3275 \\
\hline O-5 & 77 & 5.0405 & 7.9791 & $0.1100 \pm 0.089$ & $0.1927 \pm 0.0032$ & 0.000110 & 0.1349 & 0.4722 \\
\hline O-6 & 70 & 5.0410 & 7.9785 & $0.1136 \pm 0.110$ & $0.1990 \pm 0.0032$ & 0.000114 & 0.1393 & 0.4876 \\
\hline O-7 & 68 & 5.0417 & 7.9791 & $0.2698 \pm 0.078$ & $0.4727 \pm 0.0067$ & 0.000270 & 0.3309 & 1.1581 \\
\hline O-9 & 75 & 5.0419 & 7.9785 & $0.2003 \pm 0.098$ & $0.3509 \pm 0.0037$ & 0.000200 & 0.2457 & 0.8598 \\
\hline O-10 & 75 & 5.0419 & 7.9781 & $0.2357 \pm 0.099$ & $0.4129 \pm 0.0054$ & 0.000236 & 0.2891 & 1.0117 \\
\hline O-11 & 75 & 5.0421 & 7.9776 & $0.1205 \pm 0.120$ & $0.2111 \pm 0.0072$ & 0.000121 & 0.1478 & 0.5172 \\
\hline O-12 & 80 & 5.0430 & 7.9816 & $0.1183 \pm 0.087$ & $0.2073 \pm 0.0053$ & 0.000118 & 0.1451 & 0.5078 \\
\hline O-13 & 80 & 5.0436 & 7.9830 & $0.1882 \pm 0.095$ & $0.3297 \pm 0.0069$ & 0.000188 & 0.2308 & 0.8078 \\
\hline O-14 & 78 & 5.0461 & 7.9810 & $0.1175 \pm 0.097$ & $0.2059 \pm 0.0067$ & 0.000118 & 0.1441 & 0.5044 \\
\hline O-15 & 75 & 5.0441 & 7.9736 & $0.1107 \pm 0.103$ & $0.1939 \pm 0.0039$ & 0.000111 & 0.1358 & 0.4752 \\
\hline O-16 & 75 & 5.0447 & 7.9754 & $0.1255 \pm 0.085$ & $0.8795 \pm 0.0043$ & 0.000126 & 0.1539 & 0.5387 \\
\hline O-18 & 79 & 5.0349 & 7.9783 & $0.1077 \pm 0.112$ & $0.1888 \pm 0.0058$ & 0.000108 & 0.1321 & 0.4625 \\
\hline O-19 & 65 & 5.0350 & 7.9797 & $0.1350 \pm 0.125$ & $0.2366 \pm 0.0017$ & 0.000135 & 0.1656 & 0.5796 \\
\hline Minimum & & & & $0.0714 \pm 0.106$ & $0.1251 \pm 0.0398$ & 0.000071 & 0.0876 & 0.3064 \\
\hline Maximum & & & & $0.2693 \pm 0.106$ & $0.8795 \pm 0.0398$ & 0.000269 & 0.3309 & 1.1581 \\
\hline Mean & & & & $0.1454 \pm 0.106$ & $0.2835 \pm 0.0398$ & 0.000142 & 0.1742 & 0.6097 \\
\hline
\end{tabular}

Table 2: Equivalent Dose Rate $\left(\mathrm{Ht}_{\mathrm{i}}\right)$, Annual Equivalent Dose Rate $\left(\mathrm{Ht}_{\mathrm{ai}}\right)$ External Dose $\left(\mathrm{D}_{\mathrm{i}}\right)$, Annual Effective Dose $\left(\mathrm{E}_{\mathrm{i}}\right)$ and Excess Lifetime Cancer Rate (Elcr)

\begin{tabular}{|c|c|c|c|c|c|c|c|c|}
\hline Location (Indoor) & Altitude (m) & Latitude & Longitude & $\mathrm{HT}_{\mathrm{i}}(\mu \mathrm{Sv} / \mathrm{hr})$. & $\mathrm{HT}_{\mathrm{ai}}(\mathrm{mSv} / \mathrm{yr})$. & $\begin{array}{l}\mathrm{D}_{\mathrm{i}} \\
\text { (nG/hr.) }\end{array}$ & $\begin{array}{l}\mathrm{E}_{\mathrm{i}} \\
\text { (mSv/yr.) }\end{array}$ & $\begin{array}{l}\text { ELCR } \\
\times 10^{-3}\end{array}$ \\
\hline $\mathrm{I}-1$ & 80 & 5.0385 & 7.9869 & $0.1178 \pm 0.0234$ & $0.8255 \pm 0.0176$ & 0.000118 & 0.5779 & 2.0226 \\
\hline $\mathrm{I}-2$ & 81 & 5.0405 & 7.9789 & $0.1113 \pm 0.0213$ & $0.7800 \pm 0.0067$ & 0.000111 & 0.5460 & 1.9109 \\
\hline $\mathrm{I}-4$ & 56 & 5.0390 & 7.9779 & $0.0921 \pm 0.0887$ & $0.6454 \pm 0.0044$ & 0.000092 & 0.4518 & 1.5813 \\
\hline $\mathrm{I}-5$ & 72 & 5.0393 & 7.9778 & $0.1321 \pm 0.0913$ & $0.9258 \pm 0.0036$ & 0.000132 & 0.6480 & 2.2681 \\
\hline I-6 & 65 & 5.0394 & 7.9777 & $0.1010 \pm 0.0978$ & $0.7078 \pm 0.0193$ & 0.000101 & 0.4955 & 1.7341 \\
\hline $\mathrm{I}-7$ & 75 & 5.0392 & 7.9774 & $0.0901 \pm 0.0768$ & $0.6314 \pm 0.0079$ & 0.000090 & 0.4420 & 1.5469 \\
\hline $\mathrm{I}-8$ & 71 & 5.0392 & 7.9774 & $0.1123 \pm 0.0798$ & $0.7870 \pm 0.0072$ & 0.000112 & 0.5509 & 1.9281 \\
\hline I-9 & 69 & 5.0393 & 7.9774 & $0.1195 \pm 0.0888$ & $0.8375 \pm 0.0029$ & 0.00012 & 0.5862 & 2.0518 \\
\hline $\mathrm{I}-10$ & 81 & 5.0425 & 7.9811 & $0.1032 \pm 0.9011$ & $0.7232 \pm 0.0041$ & 0.000103 & 0.5063 & 1.7719 \\
\hline $\mathrm{I}-11$ & 71 & 5.0466 & 7.9772 & $0.1498 \pm 0.0451$ & $1.0498 \pm 0.0067$ & 0.00015 & 0.7349 & 2.5720 \\
\hline $\mathrm{I}-12$ & 90 & 5.0413 & 7.9827 & $0.1294 \pm 0.0733$ & $0.9068 \pm 0.0037$ & 0.000129 & 0.6348 & 2.2218 \\
\hline $\mathrm{I}-13$ & 102 & 5.0416 & 7.9749 & $0.1155 \pm 0.0566$ & $0.8094 \pm 0.0035$ & 0.000116 & 0.5666 & 1.9831 \\
\hline $\mathrm{I}-14$ & 86 & 5.0411 & 7.9757 & $0.0984 \pm 0.0662$ & $0.6896 \pm 0.0042$ & $9.84 \mathrm{E}-05$ & 0.4827 & 1.6895 \\
\hline $\mathrm{I}-15$ & 88 & 5.0404 & 7.9755 & $0.1177 \pm 0.0867$ & $0.8248 \pm 0.0063$ & 0.000118 & 0.5774 & 2.0209 \\
\hline $\mathrm{I}-16$ & 68 & 5.0404 & 7.9770 & $0.1855 \pm 0.0881$ & $1.3000 \pm 0.0071$ & 0.000186 & 0.9099 & 3.1849 \\
\hline $\mathrm{I}-18$ & 77 & 5.0388 & 7.9799 & $0.1716 \pm 0.0321$ & $1.2026 \pm 0.0049$ & 0.000172 & 0.8418 & 2.9463 \\
\hline $\mathrm{I}-19$ & 88 & 5.0380 & 7.9767 & $0.1732 \pm 0.0776$ & $1.2138 \pm 0.0038$ & 0.000173 & 0.8497 & 2.9738 \\
\hline $\mathrm{I}-20$ & 83 & 5.0356 & 7.9755 & $0.1761 \pm 0.0123$ & $1.2341 \pm 0.0057$ & 0.000176 & 0.8639 & 3.0236 \\
\hline $\mathrm{I}-21$ & 86 & 5.0356 & 7.9747 & $0.1324 \pm 0.0523$ & $0.9279 \pm 0.0045$ & 0.000132 & 0.6495 & 2.2733 \\
\hline $\mathrm{I}-22$ & 84 & 5.0398 & 7.9734 & $0.0979 \pm 0.0816$ & $0.6861 \pm 0.0039$ & 0.000097 & 0.4803 & 1.6809 \\
\hline $\mathrm{I}-23$ & 73 & 5.0365 & 7.9813 & $0.1311 \pm 0.0145$ & $0.9187 \pm 0.0036$ & 0.000131 & 0.6431 & 2.2509 \\
\hline $\mathrm{I}-24$ & 80 & 5.0404 & 7.9792 & $0.1576 \pm 0.0144$ & $0.2761 \pm 0.0087$ & 0.000158 & 0.7731 & 2.7059 \\
\hline $\mathrm{I}-25$ & 80 & 5.0404 & 7.9792 & $0.1601 \pm 0.0543$ & $0.2804 \pm 0.0023$ & 0.00016 & 0.7853 & 2.7484 \\
\hline $\mathrm{I}-26$ & 51 & 5.0398 & 7.9777 & $0.1629 \pm 0.0721$ & $0.2854 \pm 0.0062$ & 0.000163 & 0.7991 & 2.7969 \\
\hline Minimum & & & & $0.0901 \pm 0.0196$ & $0.2761 \pm 0.0519$ & 0.000090 & 0.4419 & 1.5469 \\
\hline Maximum & & & & $0.1855 \pm 0.0196$ & $1.2999 \pm 0.0519$ & 0.000185 & 0.9099 & 3.1849 \\
\hline Mean & & & & $0.1289 \pm 0.0196$ & $0.8544 \pm 0.0519$ & 0.000131 & 0.6452 & 2.2583 \\
\hline
\end{tabular}

Fig 1 is the contour map for the equivalent dose rate for the entire study area. The result here indicates that the mean equivalent dose for the outdoor is higher than that of the indoor locations. This is plausible due to the contribution of the heaps of rock and other building materials and waste materials found outdoor. From the contour map the equivalent rate is higher at the northeastern part of the study area. 


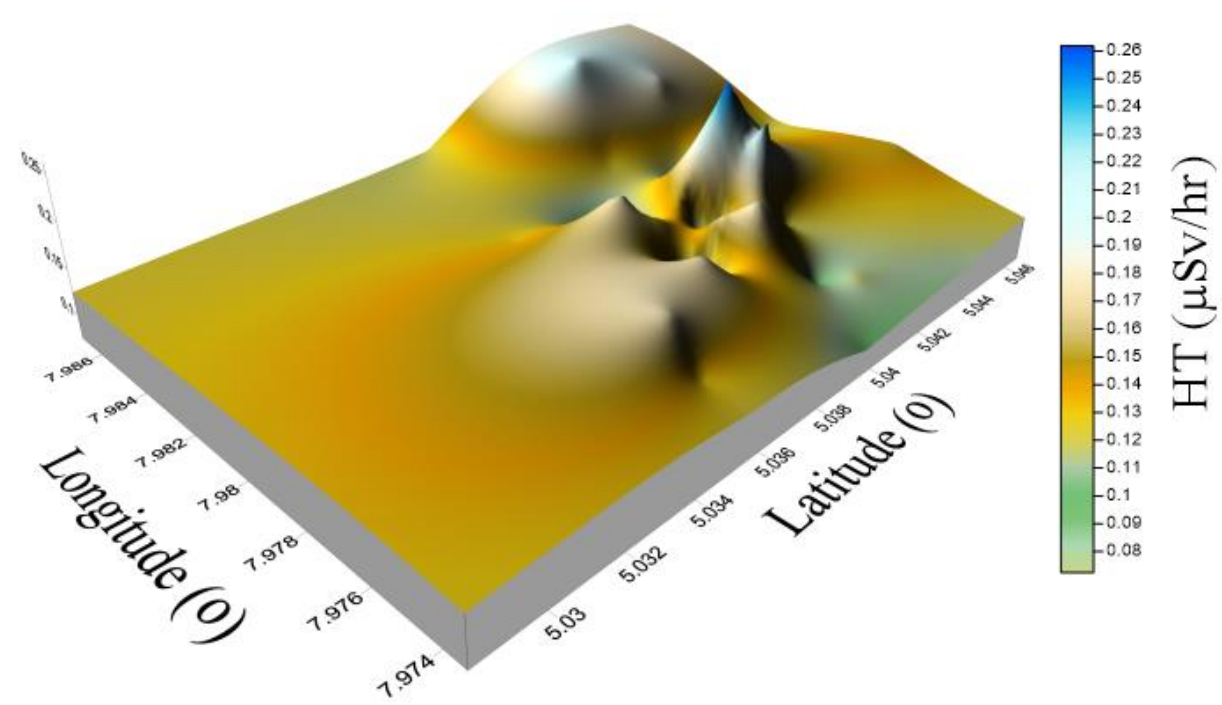

Fig. 1: Contour Map Showing Equivalent Dose.

\subsection{Annual equivalent dose}

The annual equivalent dose $\left(\mathrm{HT}_{\mathrm{a}}\right)$ is calculated from the (HT) values for outdoor $\left(\mathrm{HT}_{\mathrm{ao}}\right)$ and indoor $\left(\mathrm{HT}_{\mathrm{ai}}\right)$ using equations (2) and (3) respectively. The result of our calculations are shown in Tables 1 and 2 for outdoor and indoor annual equivalent doses respectively. $\mathrm{HT}_{\text {ao }}$ values ranges from 0.125 to 0.879 with a mean value of $0.284 \mathrm{mSv} / \mathrm{yr}$., while $\mathrm{HT}_{\mathrm{ai}}$ values ranges from 0.276 to 1.299 with a mean of $0.854 \mathrm{mSv} / \mathrm{yr}$., this is less than $2.4 \mathrm{mSv} / \mathrm{yr}$., which is the world average equivalent dose for human as stipulated by UNSCEAR (2000). Equally, our mean value is below the recommended annual stochastic limit of $1 \mathrm{mSv} / \mathrm{yr}$. for the general public (Lewis et al 1999). Fig 2 shows the contour map of the annual equivalent dose rate of the entire study area. Its highest annual equivalent dose rate value is at the north eastern part of the study area and varies with high and low annual equivalent dose rate around the study area. This is probably due to the fact that north eastern part of the study has more of the indoor locations with occupancy factor of 0.8 as compared to the outdoor locations with 0.2 occupancy factor.

\subsection{Annual effective dose}

In this work both annual effective dose for outdoor $\left(\mathrm{E}_{\mathrm{O}}\right)$ and annual effective dose for indoor $\left(\mathrm{E}_{\mathrm{i}}\right)$ are considered.

\subsubsection{The annual outdoor effective dose (EO)}

The $E_{o}$ is calculated employing the outdoor external dose $\left(D_{o}\right)$, occupancy factor or proportion of the total time in the outdoor which an individual is exposed to the radiation $\mu_{\mathrm{o}}=0.2 \mathrm{of} 8760 \mathrm{hr}$ within a year and the conversion factor $(\mathrm{CF})=0.7 \mathrm{SvGy}^{-1}$ ) for converting the absorbed dose in air to effective dose.

The equation given by UNSCEAR (2000) and Qureshi et al (2014) as:

$E_{o}=D_{o}\left(n G y h r^{-1}\right) \times 0.2 \times 8760 h r \times 0.7 S v G y^{-1} \times 10^{-3}$

Was used for estimation of annual outdoor effective dose Where

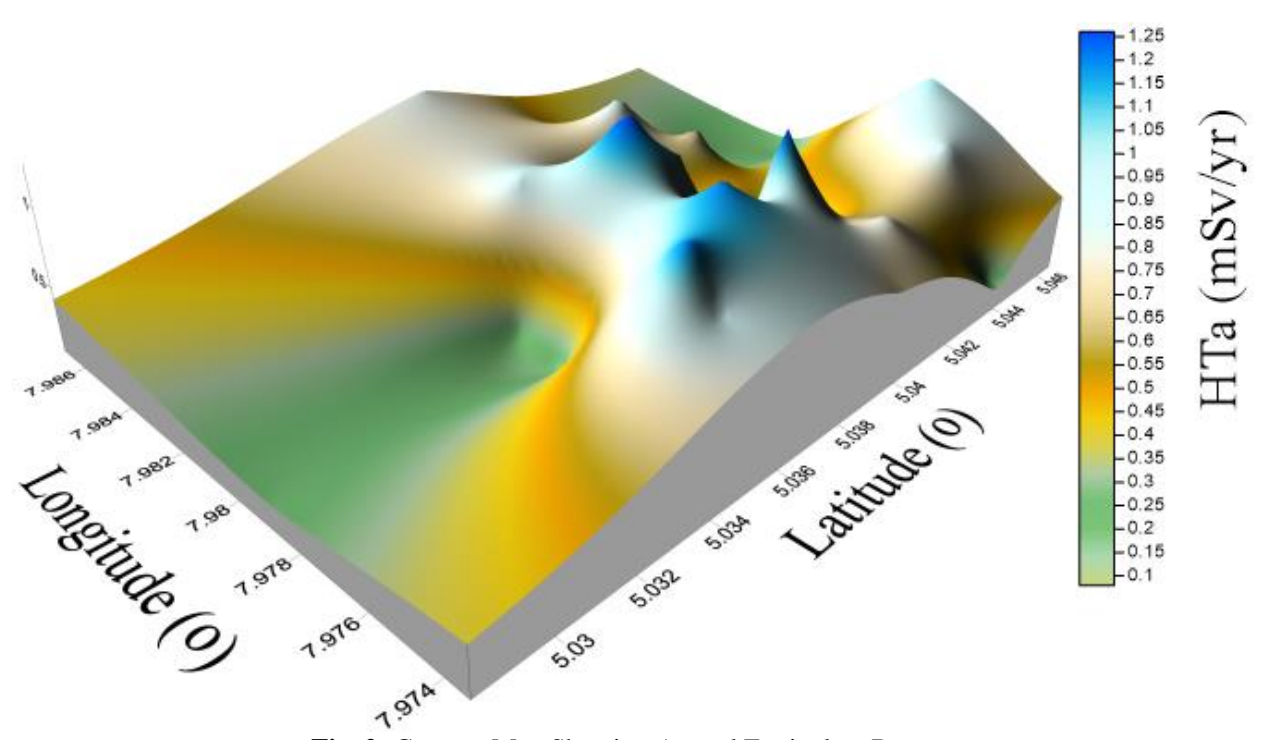

Fig. 2: Contour Map Showing Annual Equivalent Dose. 

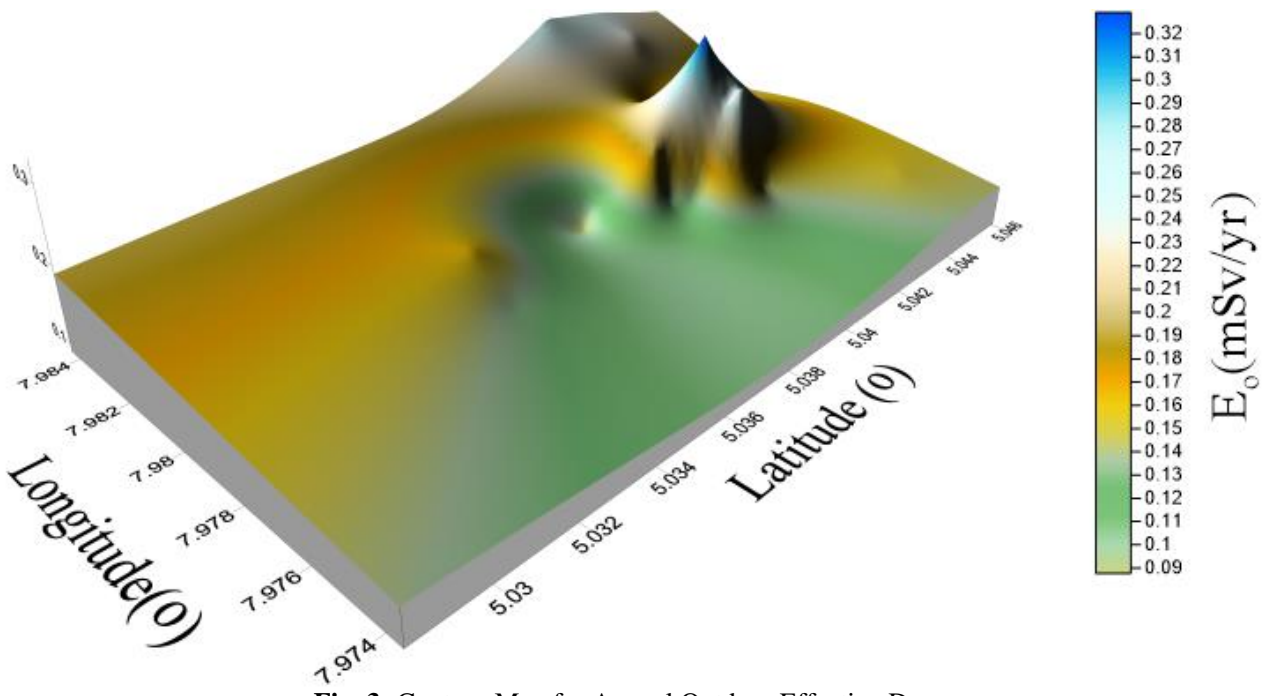

Fig. 3: Contour Map for Annual Outdoor Effective Dose.

From our calculation as seen in Table 1 the values $\left(E_{0}\right)$ ranges from 0.088 to $0.331 \mathrm{mSv} / \mathrm{yr}$. with a mean value of $0.174 \mathrm{mSv} / \mathrm{yr}$. The value is higher than the world's average of $0.07 \mathrm{mSv} / \mathrm{yr}$. stipulated in Qureshi et al (2014) report. Judging from the outdoor effective dose rate in Fig 3, the highest outdoor effective dose rate is observed at the north eastern part of the study area. It decreases from the north eastern part to the north western part of the study area.

\subsubsection{The annual indoor effective dose (Ei)}

The $E_{i}$ is calculated using the indoor external dose $D_{i}$, occupancy factor for indoor $\mu_{\mathrm{i}}=0.8$ of $8760 \mathrm{hr}$ within a year and the conversion factor $(\mathrm{CF})=0.7 \mathrm{SvGy}^{-1}$ for converting the absorbed dose in the air to effective dose. The equation given by Qureshi et al (2014) and UNSCEAR (2000) as;

$E_{i}=D_{i}\left(n G y h r^{-1}\right) \times 0.8 \times 8760 h r \times 0.7 S v G y^{-1} \times 10^{-3}$

For estimation of annual indoor effective dose was employed for calculation of $\mathrm{E}_{\mathrm{i}}$

Where
$D_{i}\left(n G y h r^{-1}\right)=\frac{H T_{i}\left(\mu S v h r^{-1}\right)}{Q} \times 10^{-3}$

Looking at the contour map for indoor effective dose rate in fig 4, it can be seen that the indoor effective dose concentration is high within the South western region of the study area. This agrees with what we have in fig 2 indicating highest values for indoor annual equivalent dose rate within the south eastern portion of the study area. Our result as seen also in Table 2 reveals a range of annual indoor effective dose rate of 0.442 to 0.910 with a mean value of $0.645 \mathrm{mSv} / \mathrm{yr}$. This value is higher than the reported world's average of $0.41 \mathrm{mSv} / \mathrm{yr}$. (UNSCEAR, 2000).

The total mean annual effective dose $(\mathrm{Eo}+\mathrm{Ei})$ estimated for the study area is seen to be $(0.174+0.645) \mathrm{mSv} / \mathrm{yr}$., giving $0.819 \mathrm{mSv} / \mathrm{yr}$., which is $57.5 \%$ higher than the world's average estimated by UNSCEAR (2000) as $0.52 \mathrm{mSv} / \mathrm{yr}$. Our mean value for the study area is lower by $48.0 \%$ than the criterion limit of $1 \mathrm{mSv} / \mathrm{yr}$. stipulated by ICRP-60 for general public and $20 \mathrm{mSv} / \mathrm{yr}$. for occupational workers. Fig 5 is a contour map showing the spatial distribution of total annual effective dose in the study area, this shows that the highest value of annual effective dose is at the Northern part of the study area.
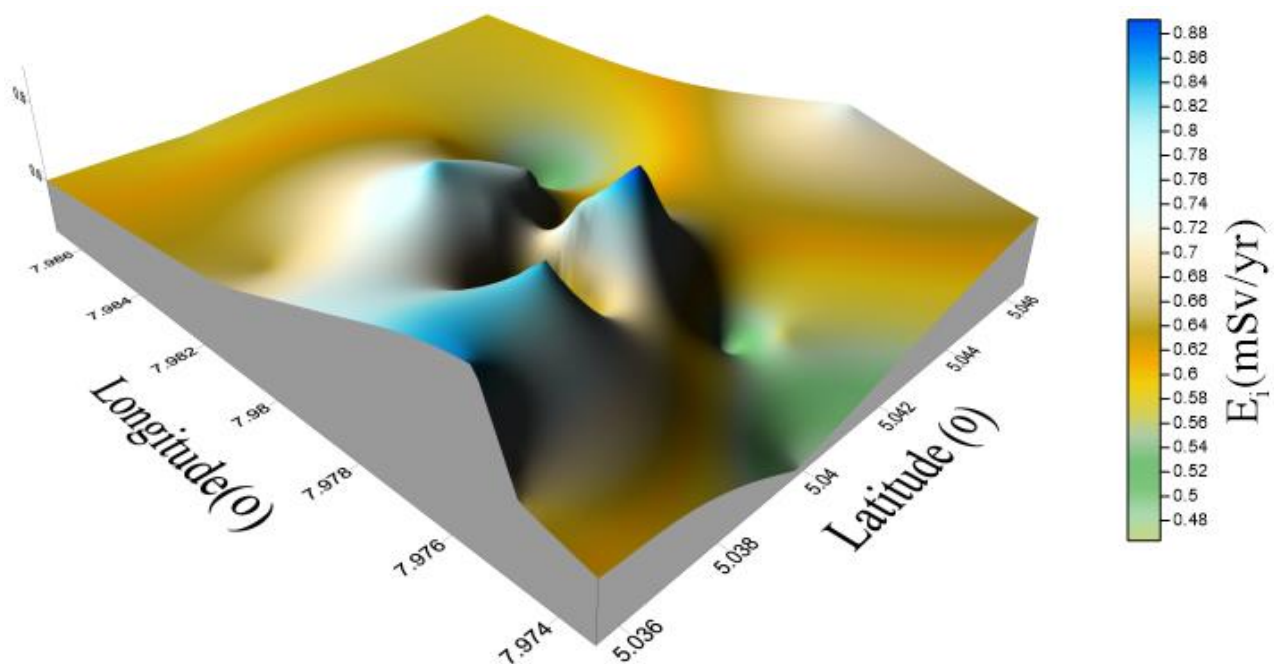

Fig. 4: Contour Map for Annual Indoor Effective Dose. 

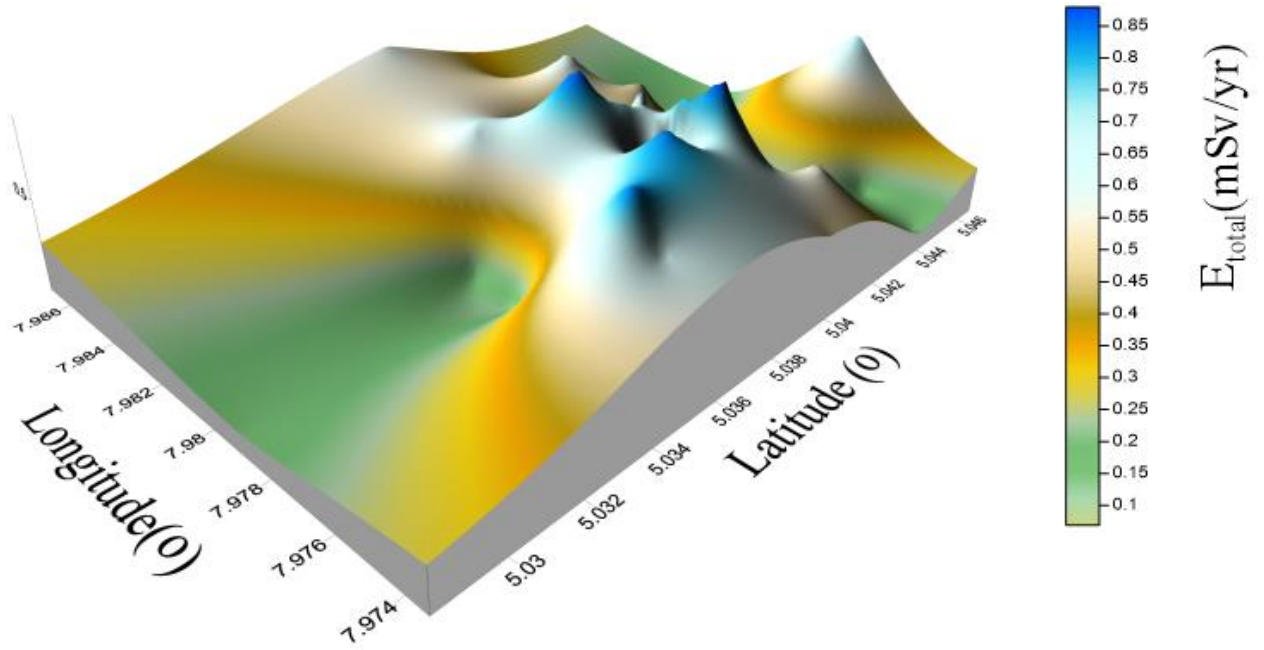

Fig. 5: Contour Map for Spatial Distribution of Annual Effective Dose.

Conti et al (1999) reporting on effective dose define the effective dose as the risk weighted summation of the equivalent dose in the tissues and organs of the body, expressing it as

$$
E=\sum_{T} W_{T} H_{T}
$$

Where ${ }^{W_{T}}$ is the tissue weighing factor of the organ or tissue $\mathrm{T}$ and ${ }^{H_{T}}$ is the equivalent dose in the organ or tissue T.

The equivalent dose ${ }^{H_{T}}$ in the organ or tissue (T) is copiously defined as the product of the mean absorbed dose in the organ or tissue and a radiation weighing factor WR. WR value depends on the type of radiation. International Commission on Radiological Protection (1990) and ICRU-60 (1991) give a factor of 1 as radiation weighing factor for gamma rays. This makes HT = DT for gamma rays. DT being the mean absorbed dose in an organ or tissue (T).

Employing the data on radiation weighting factor (WR) given by ICRU-60 (1991) and data given on tissue weighting factor (WT) by ICRU-60 (1991), coupled with the effective dose values determined in this work absorbed dose in each of the organ for the location can be calculated using equation (8).

\subsubsection{Excess lifetime cancer risk (ELCR)}

Excess lifetime cancer risk (ELCR), which depends on annual effective dose value, was calculated for outdoor and indoor locations within the study area exploring the equation expressed by Qureshi et al (2014) and Taskin et al (2009) thus:

\section{$\mathrm{ELCR}=\mathrm{E} \times \mathrm{LE} \times \mathrm{RF}$}

For calculation of ELCR in outdoor location we have

$\mathrm{ELCR}=$ Eo $\times$ LE $\times \mathrm{RF}$

And

$\mathrm{ELCR}=\mathrm{Ei} \times \mathrm{LE} \times \mathrm{RF}$

For indoor environment

Where $\mathrm{E}$ is annual effective dose generally, Eo and Ei are annual outdoor effective dose and annual indoor effective dose respectively, LE is life expectancy (70), while RF is fatal risk factor in per Sievert and it is pegged at 0.05 per Sievert (ICRP-60).

The calculated ELCR for the outdoor environment ranges from $0.31 \times 10-3$ to $1.5 \times 10-3$ with a mean value of $0.6 \times 10-3$. This mean value agrees with the report of Agbalagba et al 2010 for Enugu. The range for the indoor environment is $1.55 \times 10-3$ to $3.18 \times 10-3$ with a mean value of $2.26 \times 10-3$.

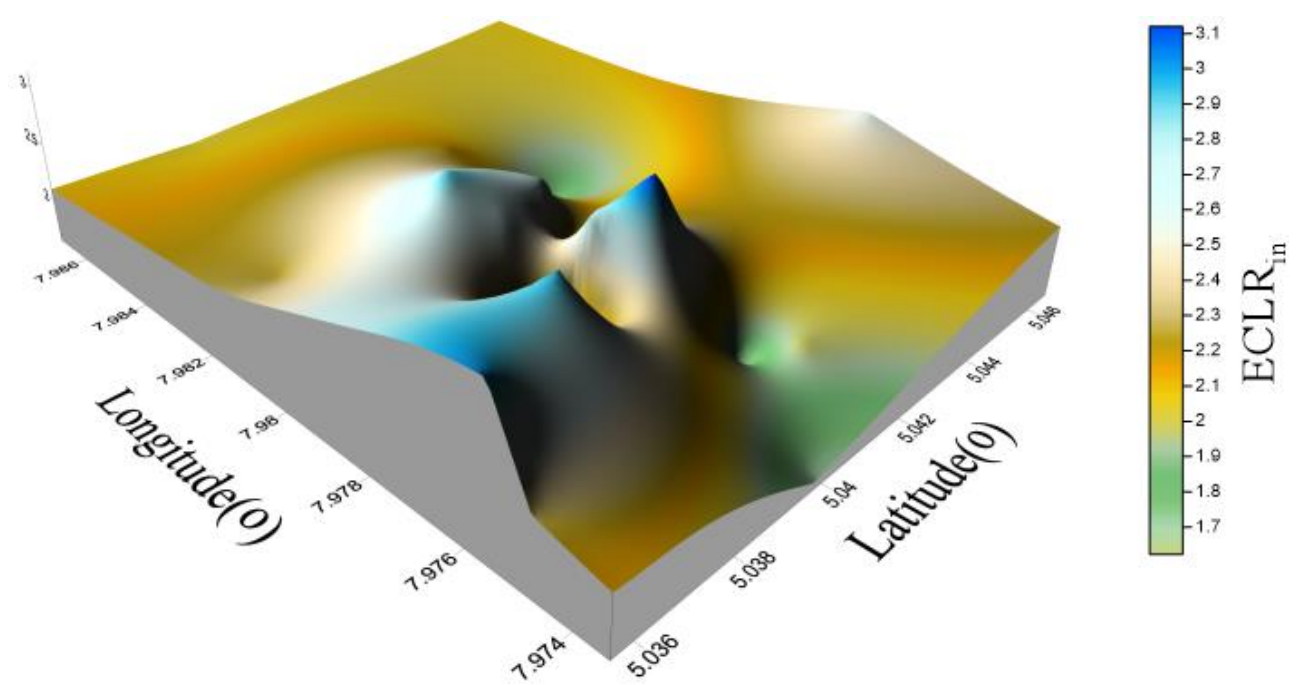

Fig. 6: Contour Map for ELCR Indoor. 


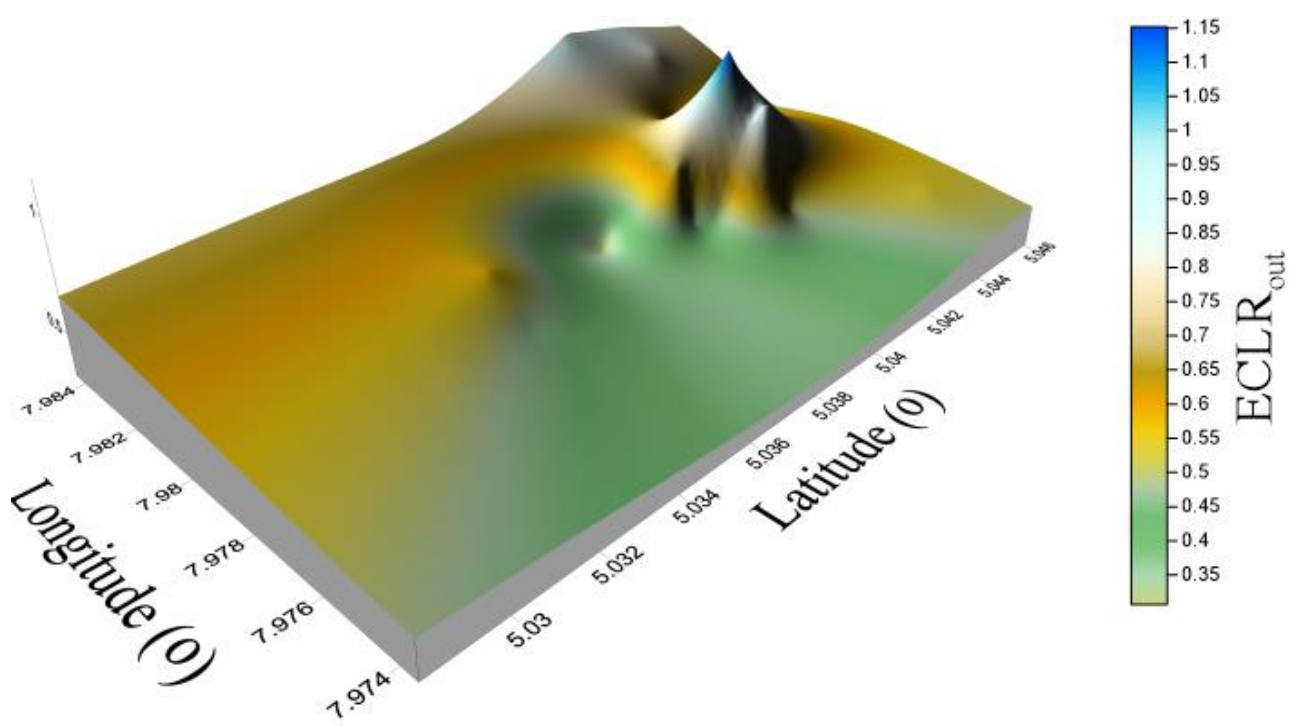

Fig. 7: Contour Map for ELCR Outdoor.

The total ELCR ranges from $1.85 \times 10-3$ to $4.34 \times 10-3$ with a mean total value of $2.87 \times 10-3$. The mean total ELCR is higher than the world's average of $1.45 \times 10-3$ by $97.9 \%$. The contour map for excess lifetime cancer risk for indoor exposure (fig 6) show a high value of ELCR within the north central region of the study area. Whereas, the contour map for excess lifetime cancer risk for outdoor exposure (fig 7) within the study area indicates high value at the north east region of the study area.

\section{Discussion}

In this paper an account of background radioactivity measurement, activity concentration radiation indices and excess lifetime cancer risk estimations carried out within the permanent site of the University of Uyo at Use Offot, Uyo, Akwa Ibom state in Nigeria is presented.

It is obvious that long term exposure to radiation may cause cancer. National Cancer Institute (2009) has it that American men have a $44 \%$ lifetime cancer risk whereas the percentage of cancer risk for women is estimated at $38 \%$ lifetime cancer risk.

The mean excess life time cancer risk (ELCR) factor calculated for indoor in this present work is $2.25 \times 10^{-3}$ which is $94 \%$ above the world's average of $1.16 \times 10^{-3}$ for indoor. Our calculated mean ELCR value for outdoor is $0.61 \times 10^{-3}$ which gives $110 \%$ higher than the world average of $0.29 \times 10^{-3}$ for outdoor. Our total estimated mean ELCR value for both indoor and outdoor stands at $2.86 \times 10^{-3}$ that is $97 \%$ higher than the world's total ELCR average of $1.45 \times 10^{-3}$.

Some studies have been carried out on ELCR at different locations in Nigeria including the work of Etuk et al (2016), Agbalagba (2016), Okeyode and Jibiri (2013), Avwiri et al (2013). Their reports, however are not reflecting the total ELCR for the locations but some report for indoor in their study location while others report for outdoor, for instance Agbalagba (2016) reports an average total ELCR of $0.61 \times 10^{-3}$ for outdoor for Warri and Effurun, Agbalagba's value is the same as our mean total for outdoor. Their report does not show value for the indoor. Okeyode and Jibiri (2013) report an average total ELCR for indoor to be $0.143 \mathrm{x}$ $10^{-3}$ for building materials from Ogun river. Their value though less than our mean indoor value does not show value for outdoor. Avwiri et al (2013) report $0.152 \times 10^{-3}$ indoor average total ELCR for soil profile for Ogba/Egbema/Ndoni local government area of Rivers State, Nigeria. This value is less than our value, but their report does not reflect value for outdoor.

Rafique et al (2014) reporting for indoor and outdoor in Jhelum valley in Pakistan gave an average total value of $1.629 \times 10^{-3}$ for indoor and $0.543 \times 10^{-3}$ for outdoor, making a total of $2.172 \times 10^{-3}$. Whereas Qureshi et al (2014) report an average total of $0.37 \times 10^{-3}$ for outdoor and $2.84 \times 10^{-3}$ for indoor with a total of $3.21 \times 10^{-3}$ for northern Pakistan.

The study locations for the present work are within a new site for the University where construction of new buildings including laboratories are being carried out with various types of building materials such as different rocks, metal rods, paints, metals, cement and different soil types: sand, gravels, granites and others being brought in for construction. These and other materials can contribute to background radiation concentration and radioactivity, influencing the equivalent radioactive dose and effective dose, hence excessive lifetime cancer risk.

\section{Conclusion}

It can be concluded, based on the fact earlier given, that the study locations are within a new site where constructions of buildings and other structures are currently being carried out meaning that a lot of various construction materials brought in are kept outdoor, it is plausible that these materials contribute to the level of radiation and activities, hence, higher equivalent dose for outdoor than indoor. Obviously, values of radiation indices based on equivalent dose are bound to be affected. The following was conclude the work:

1) The mean equivalent dose for the outdoor is higher than that of the indoor in the study area

2) The indoor annual equivalent dose rate for the study area is less than the world's average equivalent dose for human

3) The annual effective dose estimated for the study area is higher than the world average

The excessive lifetime cancer risk factor for the study area is 2.86 $\mathrm{x} 10^{-3}$ which is higher than the world average. This plausibly is due to rock materials and other building materials, coupled with laboratory chemicals and drugs brought into the new site. This calls for continuous monitoring and control.

\section{References}

[1] Johnstone, H. (1990) Facts on Nuclear waste and Radioactivity. Franklin watts, New York. Pp. 20- 21, 30

[2] Qureshi, A.A., Tariq, S., Din, K.U., Mauzoor, S., Calligaris, C. and Waheed, A. (2014). Evaluation of excessive lifetime cancer risk due to natural radioactivity in the rivers sediments of Northern $\mathrm{Pa}$ kistan. Journal of Radiation Research and Applied Sciences, Elsevier 7: 438 - 447. https://doi.org/10.1016/j.jrras.2014.07.008.

[3] UNSCEAR Report (1988) Sources, effects and risk of ionizing radiation. United Nations Scientific Committee on the Effects of Atomic Radiation. Report to the General Assembly with Annexes

[4] UNSCEAR Report (2013) Sources, effects and risk of ionizing radiation Vol. 1 report to the General Assembly with Scientific Annexes 
[5] UNSCEAR (2001) Hereditary Effects of Radiation. Reports United Nations Scientific Committee on the effects of Atomic Radiation.

[6] Mehra, R., Badha, K., Sonkawade, R.G., Kansal, S. and Singh, S. (2010). Analysis of terrestrial natural radionuclides in soil samples and assessment of average effective dose. Indian Journal of Pure and Applied Physics. Vol. 48 pp. 805 - 808.

[7] Mazzili B. and Saueia (1999). Radiological implications of using phosphogysum as building material in Brazil. Radiation Protection $\begin{array}{lllll}\text { Dosimetry. } & 86(1): & 63 & - & 67\end{array}$ https://doi.org/10.1093/oxfordjournals.rpd.a032927.

[8] Solomon, A.O. (1986). Structural petrographic studies of part of Igarra area, Bendel State, Nigeria. Unpublished B.Sc. Thesis. Department of Geology and mineral science, University of Ilorin, Nigeria p. 52.

[9] Rafique, M., Basharat, M., Azhar Saeed, R. and Rahamn, S. (2013) Effect of geology and altitude on ambient outdoor gamma dose rates in district Poonch, Azad Kashmir, Carpathian Journal of Earth and Environmental Sciences, 8(4): 165 - 173

[10] Ramli, A.T., Hussein, A.W.M.A., wood, A.K. (2015). Environmental 234U and 232Th concentration measurement in an area of high level natural background at Palong, Johor, Malaysia. Journal of En$\begin{array}{lllll}\text { vironmental } & \text { Radioactivity. } & 80: & 287-\end{array}$ https://doi.org/10.1016/j.jenvrad.2004.06.008.

[11] Sunday E. Etuk, Aniesua A. Essiett and Okechukwu E. Agbasi. (2017) Measurement of Outdoor Ambient Radioactive Radiation and Evaluation of Radiation Indices and Excess Lifetime Cancer Risk within Uyo, Unity Park, Uyo, Nigeria. Journal of Geography, Environment and Earth Science International 9(4): 1-9, 2017

[12] Etuk, S.E., George, N.J., Essien, I.E. and Nwokolo, S.C. (2015). A survey of Environmental Radioactivity level in Laboratories of the town campus, University of Uyo, Niger Delta Region. Advances in Applied Science Research. 4(4): 1- 5.

[13] Esen, N.U., Ituen, E.E., Ekeso, D.S. and Etuk, S.E. (2015) Assessment of environmental radioactivity level in St. Luke's hospital, Anua, Uyo. Advances in Applied Science Research 6(1): 79 - 82.

[14] Akpabio, L.E., Etuk, S.E.and Essien, K. (2005). Environmental radioactive level in Ikot Ekpene. Nigerian Journal of Space Research. 1: $180-187$.

[15] Ekpo, N.M. (1996) Top soil environmental radioactivity in Akwa Ibom state of Nigeria. Journal of Radio analytical and Nuclear Chemistry. 218(2):233 - 235. https://doi.org/10.1007/BF02039341.

[16] Chad-Umoren, Y. and Briggs-Kamara, M.A. (2010). Environmental Ionizing Radiation Distribution in Rivers State, Nigeria. Journal of Environmental Engineering and Landscape Management. 18(2): 154 - 161. https://doi.org/10.3846/jeelm.2010.18.

[17] Agbalagba, O.E and Meindinyo, R.K. (2010). Radiological impact of oil spilled environment: A case study of the Eriemu well 13 and 19 oil spillage in Ughelli region of Delta State, Nigeria. Indian Journal of Science and Technology. 3(9): $1001-1005$.

[18] Arogunjo, A.M., Parai, I.P. and Fuwape, I.A. (2004) Impact of Oil and gas industry on the Natural Radioactivity distribution in the Delta Region of Nigeria. Nigerian Journal of Physics. 16: 131 - 136

[19] Aviwiri, G.O and Ebeniro, J.O (1998) External environmental radiation in an industrial area of Rivers State. Nigerian Journal of Physics. 10: $105-107$

[20] Inyang, S.O., Inyang, I.S. and Egbe, N.O. (2009). Radiation exposure levels within timber industries in Calabar, Nigeria. Journal of Medical Physics 34(2):97 - 100. https://doi.org/10.4103/09716203.51937.

[21] Obioha, F.I. and Okonkwo, P.I. (2001). Background gamma radiation levels in the Nigeria Environment. West African Journal of Radiology. 8(1): $16-19$

[22] Sadiq, A.A., Liman, M.S., Agba, E.H., Lumbi, L.W., Gurku, M.U. and Ibrahim, U. (2010a). Occupational exposure to ionizing radiation among the workers of selected mining site of Nassarawa State, Nigeria. Integrated Journal of Science and Engineering, 9(1): $70-$ 74.

[23] Sadiq, A.A., Agba, E.H., Liman, M.S., Gurku. M.U., and Ibrahim, U. (2010b) Ionizing Radiation Level in Nigerian Cement. Integrated Journal of science and engineering. 9(1): $64-69$

[24] Avwiri, G.O. and Olatubosun, S.A (2014) Assessment of environmental radioactivity in selected dumpsites in Port Harcourt, Rivers State, Nigeria. International Journal of Scientific and Technological research, 3(4): $263-269$.

[25] Babalola, I.A. (1984). Radon measurement and Assay tailing from high natural radioactivity in Plateau State. Nigerian Journal of Science. 18(2): $92-98$.

[26] Ekpo, N.S. and Inyang, L.E.D. (1998). Radioactivity, physical and chemical parameters of underground and surface water in Qua Ibo
River Estuary, Nigeria. Environmental Monitoring and assessment 60: 47 - 55. https://doi.org/10.1023/A:1006125806581.

[27] Marilyn, E. and Maguine, J. (1995) Radiation Protection with Health Sciences 1st Edition, World Scientific Publishing, Singapore, pp. $296-316$.

[28] Ibeanu, I.G.E (1999). Assessment of radiological impacts of tin mining activities in Jos and its environs. Unpublished Ph.D. Thesis, Ahmadu Bello University, Zaria, Nigeria, p.50.

[29] UNSCEAR report (2000) Exposures from natural radiation sources, New York.

[30] Lewis, B.J., Tume, P., Bennett, G.I., Pierre, M., Green, A.R., Cousins, T., Hoffarth, B.E., Jones, T.A. and Brisson, J.R., (1999). Cosmic Radiation Exposure on Canadian-based Commercial Airline Route. Radiation Protection Dosimetry. Vol. 86. No.1, pp. 7 - 24. https://doi.org/10.1093/oxfordjournals.rpd.a032929.

[31] International Commission on Radiological Protection (ICRP) 26 (1990). ICRP Publication 26.

[32] International Commission on Radiological Protection (ICRP) 60. 1991:21, 1- 3.

[33] Taskin, H., Karavu, M., Ay, P., Topusoglu, A., Hindiroglu, S. and Karahan G. (2009) Radionuclide concentrations in soil and lifetime cancer risk due to the gamma radioactivity in Kirklareli. Turkey Journal of Environmental Radioactivity, 100: 49-53 https://doi.org/10.1016/j.jenvrad.2008.10.012.

[34] Agbalagba, O.E., Osimobi, J.C. and Avwiri, G.O. (2016). Excess Lifetime Cancer Risk from measure background Ionizing Radiation levels in Active Coal Mines sites and Eviros. Environmental Processes, pp. $1-14$

[35] National Cancer Institute, USA (2009). Surveillance, Epidemiology and End Results (SEER) program of the National Cancer Institute works to provide information on cancer among the US population

[36] Conti, C.C., Bertelli, L. and Lopes, R.T (1999) Age-dependent dose in organs per unit air kerma free-in-air: Conversion coefficients for environmental exposure. Radiation Protection Dosimetry 86(1): 39 - 44 https://doi.org/10.1093/oxfordjournals.rpd.a032923.

[37] Agbalagba, O.E. (2016). Assessment of excess lifetime cancer rate risk from gamma radiation level in Effurun and Warri city of Delta state Nigeria. Journal of Taibah University for science.

[38] Okeyode, I.C. and Jibiri (2013). Excess lifetime cancer risk assessment with the use of sediments from Ogun River Nigeria as Building. Research Journal of Physics. 7:1-8. https://doi.org/10.3923/rjp.2013.1.8.

[39] Avwiri, G.O., Egieya, J.M., Ononugbo, C.P. (2013). Radiometric Assay of Hazard Indices and Excess Lifetime cancer risk due to natural radioactivity in soil profile in Ogba/Egbema/Ndoni local government area of Rivers State, Nigeria. 4(5). Pp. $54-65$.

[40] Rafique, M., Rahman, S.U., Basharat, M., Aziz, W., Ahmad, I., Lone, K.A., and Matiullah, (2014) Evaluation of excess lifetime cancer risk from gama dose rates in Jheluum Valley. Journal of Radiation Research and Applied Science. 7:29-35 https://doi.org/10.1016/j.jrras.2013.11.005. 